\title{
Prema kontekstualnom proročkom propovijedanju
}

Filip Grujić

Baptistička crkva, Zagreb

filip.grujic88@gmail.com

UDK: 2:287;2-475;2-766

Izvorni znanstveni članak

https://doi.org/10.32862/k1.14.1.4

\section{Sažetak}

Ovaj je tekst rasprava o proročkom propovijedanju definiranom u okviru homiletike. Iznosi teološki i praktičan prikaz ovoga stila propovijedanja, dok aktivno traži način da ga kontekstualizira u hrvatskim okolnostima. Tekst nudi nekoliko odgovora na pitanje: Što je proročko propovijedanje te kako $i$ zašto se ono provodi? Ujedno služi kao izazov i početak rasprave o proročkom propovijedanju u hrvatskom kontekstu. Dok Crkva u okruženju, koje je sve više poslijekršćansko, traži načine komuniciranja Evanđelja sa širom društvenom zajednicom, svjesna da polako gubi svoj povlašteni položaj, čini se važnim ponovno pronaći taj proročki glas koji ljude i institucije moći poziva da se pomire s Bogom i da na ljudska bića počnu gledati kao na svoje bližnje, a ne kao na sredstva.

Ključne riječi: proročko propovijedanje, homiletika, društvena pravda, Poglavarstva i Vlasti, Crkva, misija, pravednost

\section{Uvod}

Mnogo je toga već rečeno i napisano na temu proročkog propovijedanja, tako da će naš doprinos ovoj važnoj homiletskoj temi biti kontekstualne naravi. U Hrvatskoj je proročko propovijedanje, kao homiletski stil, još relativno neistražena tema o kojoj se malo piše. Ovaj članak želi uvesti i predstaviti proročko propovijedanje u pogledu njegove definicije i prakse, a kako bi predložio mogući pravac i potrebu za daljnjim istraživanjem ovoga važnog homiletskog stila. U vrijeme 
kada Crkva aktivno traži nove načine smislene komunikacije s društvom i održavanja svoje Bogom dane službe, proročko propovijedanje postavlja izazov Crkvi općenito, ali i specifično Crkvi u Hrvatskoj, koju ljudi često smatraju udaljenom od stvarnosti u pogledu pravih potreba i patnji naroda. U ovom ću članku temi proročkog propovijedanja pokušati pristupiti sagledavajući istraživanja različitih stručnjaka i prakse različitih propovjednika.

Budući da riječ „proročki“ može biti dvosmislena, najprije želim definirati što je proročko propovijedanje u kontekstu ovoga članka. Iznijet ću pregled glavnih obilježja proročkog propovijedanja i kako se ono uklapa u širi homiletski projekt. Iznijet ću dva primjera proročkih propovijedi u njihovim kontekstima te analizirati način na koji su one prenijele proročku poruku, a zatim ću spomenuti različite biblijske i teološke slike koje koriste. Na kraju ću mapirati moguću putanju za proročko propovijedanje u hrvatskom kontekstu i identificirati „poglavarstva i vlasti ${ }^{\text {“1 }}$ koje proročko propovijedanje treba označiti i izazvati u hrvatskom kontekstu.

\section{Definicije}

\section{Proročki}

U današnjem vremenu riječ „proročki“ koristi se na mnogo načina, a i sam Novi zavjet spominje dar proroštva kao jedan od darova Svetoga Duha. Takve manifestacije mogu donijeti proročke poruke koje ciljaju na pojedince ili skupine, a služe kako bi ih ohrabrile, izazvale, a ponekad i dale viziju u pogledu budućnosti. Ovakva je vrsta prakse prisutna i ohrabruje se u brojnim vjerskim zajednicama. Međutim, žarište je ovoga članka istraživanje proročkog propovijedanja kao izraza koji je bliži poruci starozavjetnih proroka, čija je zadaća, između ostalog, ${ }^{2}$ bila utvrditi društveno-političku situaciju izraelskog naroda te javno izazvati, suočiti, držati odgovornim i pozvati na odgovornost institucije moći ili duhovne i religijske zastranjivače, koji su u tom vremenu provodili društvene nepravde. Oni su bili „Božji glasnici koji najavljuju sud i buduću nadu spasenja te prozivaju nepravde naroda i njihovih vođa“" (Kromminga 1960, 414).

1 Izraz „poglavarstva i vlasti“ najviše je definiralo djelo Charlesa L. Campbella (2002), u kojemu vezano uz tu temu gradi na djelima Waltera Winka i Williama Stringfellowa. Campbell ih označava kao materijalne i duhovne institucije koje utječu na ljude i na njima koriste moć.

2 Premda su se starozavjetni proroci u velikoj mjeri bavili religijskim nazadovanjem i idolopoklonstvom izraelskog naroda, mnogi su proroci intenzivno progovarali i o društvenim nepravdama te bili glas siromašnih i marginaliziranih ljudi svoga vremena. Najveći pobornici pozivanja na društvenu pravdu među prorocima bili su Amos, Mihej, Jeremija, Ezekiel i Izaija. 


\section{Poglavarstva i vlasti}

U istom kontekstu Charles L. Campbell $(2002,10)$, gradeći na misli Johna Steinbecka, tvrdi da poglavarstva i vlasti nisu „samo duhovna bića na nebesima, nego nadljudska stvorenja s vlastitim duhom i životom, kojima ljudi ne mogu upravljati, a koja oblikuju ljudske živote“. Na Campbellovu je definiciju utjecaj izvršila ona Steinbeckova (1999, 31-32) priča o „banci“, koju je napisao u vrijeme Velike industrijske krize, u kojoj banka jasno predstavlja takvu institucijsku moć, u čijoj se ruci nalaze ljudske sudbine i koja često dovodi ljude do ruba beznađa. Campbell $(2002,24)$ ističe obilježja ovih moći i poziva na „svetu“ konfrontaciju, tvrdeći da se etička pitanja, koje propovijedi oslovljavaju, ne moraju ticati isključivo moralnih borbi pojedinaca, nego odražavati čvrsti stav odupiranja poglavarstvima i vlastima koje se bune protiv Boga. Prema tomu, „proročko propovijedanje", koje ćemo u ovome članku proučavati i, u konačnici, primijeniti u hrvatskom kontekstu, oblik je etičkog propovijedanja koje ne govori samo o potrebama i nevoljama u životu kršćanskog pojedinca nego i opunomoćuje kršćansku vjersku zajednicu da djeluje kao proročki entitet u buntovnom svijetu, u kojemu institucijske i duhovne moći provode vlast te kvare i negativno utječu na društvenu pravdu, ${ }^{3}$ integritet života i različite slobode.

U hrvatskom evanđeoskom kontekstu izraz „proročko propovijedanje“ većina bi još uvijek razumjela kao vrstu propovijedanja koje je vjerojatno povezano uz proroštvo kao očitovanje Svetoga Duha, a ne uz etički oblik propovijedanja koje oslovljava "poglavarstva i vlasti“. Štoviše, potonje bi se, tradicionalno, ali ipak nespretno protumačeno iz Efežanima 6,12, najčešće smatralo isključivo kao duhovnim protivnicima kršćana. Nadalje, velik dio evanđeoskih kršćana u Hrvatskoj reći će da je uloga Crkve samo „propovijedati evanđelje“ i ne uplitati se u „pitanja ovoga svijeta“, kao što su politika, društvena pravda te pitanja koja brinu javnost, siromašne i marginalizirane. Međutim, smatram da društvene okolnosti izrazito naglašavaju potrebu za takvim propovijedanjem.

Govoreći iz sjevernoameričkoga evanđeoskog konteksta, Marvin A. McMickle poziva na smionije propovijedanje, propovijedanje koje se ne usredotočuje samo na unutarnja pitanja nego seže i do pitanja koja se tiču šire društvene zajednice izvan Crkve. Prema McMickleu (2006, 3), takvo je propovijedanje „aktivno nastojanje oko pravde i pravednosti za svakoga člana društva“. Mnogi drugi glasovi iz sjevernoameričkoga evanđeoskog konteksta, poput McMicklea, naglašavaju da je Crkva samodopadna po pitanju problema s kojima se suočava šira društvena zajednica te da većina većinskih, privilegiranih crkava žive u potpunoj

3 „Propovijedanje društvene pravde kreće od razotkrivanja i optuživanja povreda prema izlaganju Božje vizije zdravog, cjelovitog i miroljubivog života u društvenoj zajednici“ (Resner 2008, 135). 
izoliranosti od satrvenoga svijeta koji ih okružuje. Štoviše, to je razlog zašto takve crkve polagano umiru (usp. Jacobsen 2009, 13). Poput priče o milosrdnom Samarićaninu iz desetog poglavlja Evanđelja po Luki, na Crkvu se često gleda kao na religiozne ljude onoga vremena, koje u priči utjelovljuju svećenik i levit; ljude koji ignoriraju patnju ovoga svijeta jer su okrenuti prema sebi, odnosno prema svojim religijskim praksama i ritualima.

Proročko propovijedanje postavlja pitanje može li Crkva, kao nositeljica missio Dei, zbilja sebi dopustiti da je proguta "efekt promatrača" ${ }^{\mathrm{i}}$ jednostavno reći: „Pa dobro, netko će drugi doći i podići glas za društvenu pravdu, protiv rasne i mnogih drugih oblika diskriminacija, protiv siromaštva, korupcije, suvremenog ropstva te ostalih oblika nepravde?" Ovi različiti oblici patnje mogu se pripisati djelovanju i naporima pobunjenih poglavarstava i vlasti u našem svijetu, a proročka uloga Crkve treba njegovati zajednicu vjere, zauzimajući ozbiljan stav protiv institucija moći te svijetu, koji pati, pružiti zaštitu i milosrdnu Božju ruku. Umjesto toga, u Crkvi često vidimo svjetonazor koji je uvelike prilagodljiv i samodopadan, koji se ponekad previše boji progovoriti o bolnim društvenim pitanjima, često iz straha da će izgubiti svoj položaj na društvenoj platformi utjecaja i povlastica, a često i zbog manjka kritičkog prosuđivanja prema političkim namjerama. J. Phillip Wogaman $(1998,4)$ na zanimljiv način naglašava ovo ignoriranje u primjeru „njemačke crkve tijekom nacističkog režima, ${ }^{5}$ kubanske crkve u vrijeme jačanja marksističke vlasti te ruske Pravoslavne Crkve za vrijeme boljševizma“. U skladu sa svojim proročkim karakterom, Crkva bi tijekom najcrnjih trenutaka čovječanstva trebala progovarati i biti navjestitelj Božje pravednosti.

\section{Suglasnost u pogledu proročkog propovijedanja}

Među homiletičarima ne postoji jednoglasno slaganje u pogledu značenja izraza „proročko propovijedanje“, ali u ovom ću dijelu pokušati pronaći zajedničko tlo u različitim pristupima tome predmetu te istaknuti značajke koje proročko propovijedanje kao homiletička disciplina može njegovati. Već spomenuti McMickle (2006, 11-12) slaže se s Walterom Brueggemannom u vezi uloge proročkog propovijedanja kao alata pomoću kojeg se izaziva ono što on naziva „kraljevskom

4 Prema definiciji rječnika Oxford Dictionary of Psychology, „efekt promatrača“ je oklijevanje promatrača da ureduje u vrijeme hitnog slučaja i nevolje (Colman 2008, 107).

5 Sličnu situaciju vidimo u pogledu Katoličke Crkve u Hrvatskoj i njezine podrške nacionalizmu ustaškog pokreta u razdoblju od 1941. - 1945. godine. Ovu je temu obradila Irina Ognyanova (2009) u svome članku „Religion and Church in the Ustasha Ideology 1941-1945“. Croatica Christiana Periodica 33/64, 157-90. 
svijesti“" ${ }^{\text {te }}$ se za narod mapira alternativna i obećavajuća budućnost u kojoj Božja suverena vladavina može utjecati na društvene prilike i olakšati patnju koju nanose od Boga otuđene sile. Međutim, McMickle dodaje da nisu svi izraelski proroci bili pobornici društvene pravde, nego su u tome vremenu postojali i oni proroci koji se nisu zauzimali za obespravljene, već su se priklanjali dominantnoj kulturi, uživajući pritom mnoge privilegije koje je ona nudila onima koji su je podržavali i s njom se asimilirali.

Polazišna točka proročkog propovijedanja obično je procjena društvene situacije, kao i štetnih utjecaja i stvarnosti patnje. Međutim, dobro je podsjetiti se da krajnji cilj nije nihilistički prikaz sadašnjosti, nego ulijevanje nade u pogledu budućnosti. Većina će se homiletičara složiti kako je pružanje nade u životima Božjega naroda jedan od najznačajnijih ciljeva svake propovijedi. Međutim, čini se da je to još istaknutije u proročkom propovijedanju. Božje otkupiteljsko počelo proročkog propovijedanja često izlazi na svjetlo onda kada se suočava s iznimno obeshrabrujućom situacijom. Upravo ta potrebna slika jedne svjetlije budućnosti, nade i ostvarenja Božjih obećanja, važna je odlika proročkog propovijedanja (usp. Tisdale 2010, 4-9).

Ciljano je slušateljstvo još jedna iznimno važna odlika proročkog propovijedanja. Poruka proročkog propovijedanja, nasuprot onome što je postalo i previše uobičajeno u sjevernoameričkim crkvama, nije usmjerena prema potrebama pojedinaca, nego prema potrebama i često patnji šire društvene zajednice. Proročko je propovijedanje spremnije oslovljavati pitanja i životne probleme koje neke crkvene zajednice možda smatraju potpuno nesvojstvenima njihovu životnom stilu i vjerskom svjetonazoru. Stoga, i cilj proročkog propovijedanja nije toliko u izravnom smislu izgradnja, njegovanje učeništva i poučavanje usmjereno prema duhovnom rastu vjernika pojedinaca. Naprotiv, njegov je cilj osvijestiti zajednicu vjernika, pružiti nadu marginaliziranima i usprotiviti se poglavarstvima i vlastima u institucijama koje vrše ugnjetavački utjecaj. U tome smislu, usmjereno je široj društvenoj zajednici.

Proročko je propovijedanje ujedno i vizionarsko. Naravno, ne u smislu „predviđanja“ budućnosti, što bi naziv „proročki“ moguće mogao natuknuti, nego u smislu stvaranja i očitovanja vizije alternativne stvarnosti, u kojoj se poglavarstva i vlasti, koji ljude ugnjetavaju, podređuju Božjem djelovanju i misiji Božjega naroda. Upravo vizija osnažuje i podiže iste te ljude iz njihovih udobnih naslonjača samodopadnosti i komfora te ih potiče da postanu smjeli i odvažni za Božje kraljevstvo. Unatoč tomu, kada je vapaj Martina Luthera Kinga ml. pokrenuo narodne mase putem snažne poruke i vizije sna o zemlji bratstva, jednakosti,

6 Prema Brueggemannu $(2001,37)$ ova „kraljevska svijest“ odnosi se na dominantnu kulturu vremena tijekom službe izraelskih proroka, a predstavlja kraljevsku, religijsku moć, usredotočenu na očuvanje carstva, beskrupulozno gazeći po marginaliziranima i nemoćnima. 
slobode i pravde, većina je bjelačkih crkava toga vremena ostala nezainteresirana i ravnodušna (usp. Gushee 1998, 10).

Proročko je propovijedanje utemeljeno na Svetom pismu, koje ga ujedno i potpomaže, prije svega u porukama starozavjetnih proroka i u Isusovoj službi u Novom zavjetu. Starozavjetni su proroci bili pozvani razabrati okolnosti s kojima se suočavao izraelski narod u vrijeme njihove službe te postavljati prava pitanja, pozivajući narod na odgovornost zbog njihovih djela i stavova. Njihov proročki žar dolazi od snažnog osjećaja obveze prema poruci koju su primili od Boga. Prema tomu, starozavjetna proročka književnost sadrži teološke i biblijske ključeve kojima se otključavaju alati za stvaranje proročkih poruka današnjice budući da su danas teme korupcije i podmićivanja, nepoštenja i tiranije te ugnjetavanja i diskriminacije itekako prisutne. Proroci su pozivali narod da se „pomiri“ s Bogom i ljude jedne s drugima. Štoviše, Isus se u svojoj poruci uglavnom bavio siromašnima i zakinutima, bolesnima i odbačenima, prezrenima i izoliranima. „Njegov proročki identitet očitovao se kada bi ušutkao ugnjetavače i oslobodio potlačene" (Turner 2008, 101-102).

Moguće je povući poveznicu između narativnog propovijedanja, teologije oslobođenja i proročkog propovijedanja. Samo po sebi, proročko propovijedanje ne mora nužno biti u ekspozicijskom ili narativnom homiletičkom taboru jer ga prije svega definira njegov sadržaj, a ne način na koji se prenosi poruka. Međutim, moguće je istaknuti način na koji su induktivan pristup ${ }^{7}$ i korištenje priča pri komunikaciji značenja povezani s prihvaćanjem proročke poruke. Afroamerička teologija oslobođenja, kao i njezino propovijedanje u vrijeme djelovanja pokreta za društvena prava, znala je oživjeti starozavjetne biblijske naracije dok bi mnoštvo slušatelja zorno ponovno proživljavalo borbu Mojsija i Božjega naroda protiv ugnjetavanja i ropstva, kao i avanture proroka koji su se borili protiv vladajućeg establišmenta onoga vremena. ${ }^{8}$ Još jedan argument u prilog narativnom karakteru proročkog propovijedanja nalazimo u činjenici da stvarnosti društvene nepravde i ugnjetavanja, kao i djelovanje poglavarstava i vlasti, često dođu u svijest prosječnog člana većinske Crkve kada propovjednik tu stvarnost prenese koristeći životne priče. Prema tomu, stvarne životne priče, zajedno s povezanim biblijskim naracijama, tako postaju moćni i važni propovjednički alati za stvaranje potresnih trenutaka u kojima se u zajednici javlja svijest, ali i nameće pitanje: "Je li moguće da se ovo zbilja događa među nama?“

7 Induktivno propovijedanje kreće od iskustva prema općoj istini nasuprot deduktivnom propovijedanju (usp. Craddock 1983, 55).

8 McClure $(2007,11)$ iznosi sljedeću tvrdnju: „U afroameričkoj tradiciji, proročko propovijedanje poistovjećuje biblijsku naraciju sa slušateljevom vlastitom pričom, pričom koja se kreće od patnje i tužaljke ka oslobođenju i nadi. Crnačka tradicija društvenog proroštva također povezuje proročko propovijedanje s praktičnom teologijom novačenja, pastoralne brige i organizacije zajednice za društveno djelovanje." 


\section{Proročko propovijedanje na djelu}

$\mathrm{U}$ ovom ću dijelu članka predstaviti dva primjera proročkog propovijedanja u baptističkom kontekstu, a zatim ih analizirati s gledišta kulturološke pozadine, biblijskih i teoloških tema te njihova načina izražavanja. Prvu je propovijed iznio Karl B. Johnson, glavni tajnik Baptističkog saveza Jamajke, prilikom komemoracije Dana emancipacije na Jamajci. Johnson oslovljava odgovornost u upravljanju slobodom koju je njihov narod primio, a svoj argument provlači kroz biblijsku poredbu o izgubljenom, odnosno razmetnom sinu. Njegovo je slušateljstvo šire od mjesne Crkve, pa čak i od denominacije. Johnson oslovljava državu Jamajku kao cjelinu i antropomorfno je uspoređuje s razmetnim sinom kojemu je otac dao slobodu i koji je stoga preuzeo odgovornost upravljanja novopronađenim životom. Johnson $(2014,128-36)$ Jamajku prikazuje kao razmetnoga sina u tri zajedničke točke: kao sina koji je „izgubio svoj identitet, protratio svoje nasljeđe i napustio svoju moralnost“. Njegova je propovijed dobar primjer korištenja novozavjetnih poredbi u svojstvu naracijâ koje pokreću proročko propovijedanje unatoč tome što sama propovijed nije narativna, nego deduktivna.

Johnsonova $(2014,130)$ ključna biblijska tema jest nesposobnost razmetnoga sina da upravlja slobodom koju je primio, tako da postoje lekcije koje su povezane s kronologijom Jamajke nakon emancipacije. Njegov je jezični stil „asertivan i evokativan“ jer upućuje na jamajčanske kulturološke izraze i njima specifičan izričaj. ${ }^{9}$ Johnson se poziva na divljenja vrijednu snagu, robusnost i otpornost Jamajčana, koju su pokazali u prošlosti kada su se suočili s nemirom i ugnjetavanjem. Iste su to kvalitete koje želi dozvati u misli dok poziva narod da se zajedno suoče s utjecajima koje označava kao negativne čimbenike sadašnjega vremena. Johnsonova propovijed poziva nas da se odupremo onome što bismo mogli nazvati „poglavarstvima i vlastima“. On ističe „dominantne imperijalističke sile današnjice“, koje oblikuju nove naraštaje Jamajčana, tako da oni polako gube taj svoj istaknuti identitet koji Johnson iznimno cijeni. Ističe loše upravljanje prirodnim resursima zemlje, kao i kulturom i njezinim narodom, što je jasan izazov „,ladajućoj garnituri“. Nadalje, ističe i proziva „kockarsku industriju“ koju vidi kao najjasniju prijetnju moralnim vrijednostima i načelima svoje zemlje.

Johnson svoju propovijed završava Radosnom viješću, podsjećajući sve da se istinska sloboda doživljava u Bogu kada dođe do promjene pravca. Johnsonova propovijed o „razmetnoj zemlji“ potkrepljuje značajke proročkog propovijedanja, dok svoju poruku usmjerava široj društvenoj zajednici, pruža evokativnu

9 Johnson $(2014,135)$ koristi izraze i izreke jamajčanskog dijalekta, poput „No weh nuh better than yaad“, koja znači „Nigdje nije bolje nego kod kuće“. 
viziju i nadu za budućnost, imenuje i proziva poglavarstva i vlasti te koristi biblijsku naraciju kako bi svoje slušatelje smjestio u sandale razmetnoga sina.

Drugi primjer propovijedi dolazi iz jednog malo drukčijeg konteksta, a riječ je o propovijedi Solomona Ademole Isholaha, bivšega glavnog tajnika Nigerijske baptističke konvencije, pod naslovom „Svrha privilegiranog života“. Isholah oslovljava nigerijske političke vođe putem biblijske pouke o svrsi privilegiranoga života, koji opisuje kao život ljudi koji služe u političkoj i upravnoj vlasti. Isholah svoju tvrdnju temelji na tekstu u Rimljanima 13,1-7, a kaže da je odgovornost sudjelovanja u vlasti znak Božje blagonaklonosti (privilegije) te da je prate uzvišeni poziv i svrhovitost. Dok tumači tekst, Isholah $(2014,37)$ iz njega izvlači pouke nigerijskim upravnim tijelima, pozivajući ih u šest točaka da „budu Božji sluge, dodaju vrijednost životima ljudi, čuvaju pravednost dok se suočavaju sa zlom, sačuvaju čistu savjest, koriste poreze za javno dobro i budu marljivi i predani“. Ciljano slušateljstvo ove poruke su nigerijski politički vođe, ali zbog prirode njihove uloge, posljedice ove poruke prelijevaju se i na šire društvo.

Isholah pripadnike vlasti izaziva i poziva da se pomire s Bogom i obnove borbu za dobrobit nigerijskog naroda, a protiv korupcije, pravosudne pristranosti, nezakonite dobiti i rasipnosti političkih vođa. Njegova poruka odiše hrabrošću, što proizlazi iz konteksta u kojem ju je iznio, u prisutnosti mnogih političkih vođa te zemlje, tako da je njegova poruka bila izravno sučeljavanje. Isholah $(2014,33)$ staje na stranu nigerijskog naroda kada traži ,dobre ceste, pitku vodu, neprekinutu i stabilnu struju, dobre i adekvatno opremljene bolnice, okruženje prikladno za ekonomski rast i poslovne mogućnosti za mlade ljude“. Kroz cijelu propovijed provlači biblijske teme i kratke naracije o Danielu i Josipu, koje označava kao pobožne vođe i dobre upravitelje, dok cijelo vrijeme egzegetski izlaže Rimljanima 13 i Pavlovo učenje o pokoravanju vlastima. Njegov je izričaj snažan, odvažan i proročki, a ne bježi ni od korištenja usklika, poput „Dosta je bilo!“ dok govori licem $u$ lice predstavnicima vlasti. Isholahova propovijed o „privilegiranim vođama" odjekuje proročkim propovijedanjem jer je usmjerena predstavnicima vlasti koji izvršavaju utjecaj u široj društvenoj zajednici, imenuje i proziva buntovnu zloporabu moći i vlasti te koristi biblijske ličnosti kao dobre primjere upravljanja i društvene pravde vezano uz situaciju u Nigeriji.

Iz ove dvije propovijedi moguće je izvući neke usporednice. Zanimljivo je da je povod obje propovijedi komemorativna prigoda, ${ }^{10}$ koja možda može pružiti jedan smioniji naboj za izražavanje proročke poruke, kao i omogućiti da poruku slušaju predstavnici vlasti, čime će se zajamčiti da poruka dođe do onih koji je u konačnici i trebaju čuti. Nadalje, očigledno je da u obje propovijedi dolazi do mo-

10 Johnsonova prigoda bila je komemoracija neovisnosti Jamajke, dok se u Isholahovu slučaju radilo o rođendanu visoke političke ličnosti, izvršnoga guvernera države Oyo. 
menta u kojem propovjednik poziva na vrijednosti i vrline svoga naroda ili kulture, kao i na mnoge prednosti i blagoslove u kojima zemlja uživa. Poglavarstva i vlasti se ne mogu tek nejasno iščitati između redaka, nego ih se u obje propovijedi jasno imenuje i oslovljava, a obje propovijedi koriste biblijske naracije i biblijske ličnosti kao analogije pomoću kojih se ukazuje na trenutnu situaciju.

\section{Hrvatski kontekst}

Pitanje, koje se polako oblikovalo u mome razmišljanju od trenutka kada je proročko propovijedanje postalo tema koja me je zaintrigirala, bilo je: „Kako mogu ovo primijeniti u vlastitu kontekstu?" Slično američkom kontekstu, o kojemu je pisao McMickle (2006, 30-31), Crkva u Hrvatskoj ograničava svoju borbu za pravdu prvenstveno na dva pitanja: pobačaj i seksualnost. Štoviše, zanimljivo je da evanđeosko društvo u Hrvatskoj, ${ }^{11}$ premda obično iznimno kritično i skeptično u pogledu Rimokatoličke Crkve, ne vidi nikakav problem u udruživanju u zajedničku borbu po ovim pitanjima. Nažalost, ostala pitanja društvene pravde rijetko se spominju u propovijedima i medijskim izjavama religijskih vođa. Puno toga bismo mogli reći o političkom angažmanu, položajima moći i političkoj pristranosti kojima svjedočimo od strane dominantnih religijskih izričaja u Hrvatskoj. Ipak, moramo biti pošteni i reći kako se slični primjeri zloporabe religijske političke moći javljaju i u dominantno evanđeoskim zemljama. Bilo bi zanimljivo dalje istražiti način na koji se Campbellova definicija poglavarstava i vlasti primjenjuje na crkvene institucije koje nisu postavljene da budu protestni glasovi, nego pak snažna i moćna većina, koja ponekad ima politički utjecaj. U tom slučaju postoji mogućnost da očituju neke od značajki koji se pripisuju poglavarstvima i vlastima. ${ }^{12}$

Hrvatskoj evanđeoskoj zajednici preostaje pitanje potencijalnog usmjerenja u pogledu iznošenja proročke poruke koja se ne bavi samo pitanjima istospolnih brakova i pobačaja nego prepoznaje poglavarstva i vlasti u Hrvatskoj i podiže glas u pogledu pitanja poput visoke nezaposlenosti i siromaštva, migracije mlade i visokoobrazovane radne snage, korupcije na najvišim razinama političke moći, kao i rastućeg nacionalizma i ksenofobije. Platforma ove vrste propovijedanja ne nastaje lako s obzirom na činjenicu da je evanđeoska zajednica u Hrvatskoj veoma mala u usporedbi s dominantnom religijom. Međutim, za razliku od Isholahove

11 Pod „evanđeoskom zajednicom u Hrvatskoj“ razumijem sve one crkve koje bismo mogli staviti pod zajednički nazivnik, odnosno crkve koje teolozi poput McClendona i Parusheva na engleskom jeziku nazivaju „baptistic“, a odnose se na crkve koje krštavaju isključivo vjernike: baptističke, pentekostalne, Kristove crkve i druge slobodne evanđeoske crkvene zajednice.

12 Isto pitanje može se postaviti i o američkoj evanđeoskoj crkvi. 
propovijedi, koja je bila usmjerena izravno predstavnicima vlasti, hrvatski evanđeoski kršćani svoju snažnu i smionu viziju mogu propovijedati u svojim zajednicama i opunomoćiti svoje vjerske zajednice da se upuste u društvene pothvate kojima će podizati svijest o ovim važnim društvenim temama i služiti kao narod uključen u Božju misiju. Puno toga još trebamo postići po Božjoj milosti, ali Crkva u Hrvatskoj mora čuti istaknut Božji proročki poziv „Koga da pošaljem?“i na njega hrabro odgovoriti „Evo nas!“

\section{Zaključak}

Proročko propovijedanje poziva nas da uputimo snažan i smion izazov poglavarstvima i vlastima koje djeluju u našem svijetu te da se priklonimo obespravljenima i marginaliziranima koji se bore s tim silama. Dok nastavlja Isusovu službu, koja je bila proročka i djelom i oslobodilačkim djelovanjem, Crkva u svojim različitim kulturama i kontekstima mora pronaći nove načine da prenese ovu proročku poruku i da se zauzme za one koji nisu kadri zauzeti se sami za sebe. Mnoge nevladine organizacije i različite društvene organizacije diljem Europe i svijeta uzele su na sebe taj proročki ogrtač, dok je Crkva često izabrala šutnju. Ipak, ne smijemo pobjeći od odgovornosti koju imamo za ovaj svijet. Crkva se mora zauzeti ne samo za pitanja morala koja nas na poseban način intrigiraju nego se s posebnom pažnjom zauzeti za patnju koja nas okružuje u našim lokalnim kontekstima te pronaći načine na koje ćemo dosegnuti šire društvo porukom oslobođenja, nade i oproštenja.

\section{Bibliografija}

Brueggemann, Walter. 2001. The Prophetic Imagination. Minneapolis: Fortress Press.

Campbell, Charles L. 2002. The Word before the Powers - an Ethic of Preaching. London: Westminster John Knox Press.

Colman, Andrew M. 2008. A Dictionary of Psychology. Oxford: Oxford University Press.

Craddock, Fred B. 1983. As One without Authority. Nashville TN: Abingdon Press.

Gushee, David P., i Robert H. Long. 1998. A Bolder Pulpit: Reclaiming the Moral Dimension of Preaching. Valley Forge: Judson Press.

Isholah, Solomon Ademola. 2014. „The Purpose of a Favoured Life“. U Baptist Preaching: A Global Anthology, urednik Joel C. Gregory, 29-37. Waco: 
Baylor University Press.

Jacobsen, David Schnasa. 2009. „Schola Prophetarum: Prophetic Preaching Toward a Public, Prophetic Church“. Homiletic, 34/1, 12-21.

Johnson, Karl B. 2014. „Commemorating Jamaica’s Emancipation“. U Baptist

Preaching: A Global Anthology, urednik Joel C. Gregory, 128-36. Waco: Baylor University Press.

Kromminga, Carl G. 1960. „Preaching“. U Baker's Dictionary of Theology: Preach, Preaching, urednici Everett Falconer Harrison, G. W. Bromiley i Carl F. H. Henry, $414-15$. London: Pickering \& Inglis Ltd.

McClure, John S. 2007. Preaching Words: 144 Key Terms in Homiletics. Louisville: Kentucky: Westminster John Knox Press.

McMickle, Marvin A. 2006. Where have all the Prophets Gone? - Reclaiming Prophetic Preaching in America. Cleveland: The Pilgrim Press.

Resner, André. 2008. „Social Justice“. U The New Interpreters Handbook of Preaching, urednik Paul Scott Wilson, 135-37. Nashville: Abingdon Press.

Steinbeck, John. 1999. The Grapes of Wrath, Penguin Great Books of the Twentieth Century. New York: Penguin Books.

Tisdale, Leonora Tubbs. 2010. Prophetic Preaching: A Pastoral Approach. Louisville: Westminster John Knox Press.

Turner, Mary Donovan. 2008. „Prophetic Preaching“. U The New Interpreter's Handbook of Preaching, urednik Paul Scott Wilson, 101-02. Nashville: Abingdon Press.

Wogaman, Phillip J. 1998. Speaking the Truth in Love: Prophetic Preaching to a Broken World. Louisville: Westminster John Knox Press.

Prevela s engleskog Ivana Balint Feudvarski

Filip Grujić

\title{
Towards Contextual Prophetic Preaching
}

\begin{abstract}
Summary
This text is a discussion about prophetic preaching as defined in the boundaries of homiletics. It offers both a theological and practical presentation of this preaching style actively seeking a way to contextualize it in Croatian setting. It offers
\end{abstract}


some answers to the question: What is prophetic preaching and how and why it is done? It also serves as a challenge and the beginning of the discussion on prophetic preaching in Croatian context. As the Church in a growing post-Christian setting seeks ways to communicate the Gospel with the wider society aware that it is slowly losing its privileged footing it seems important to find again the prophetic voice which calls people and institutions of power to get right with God and see human beings as neighbors and not means. 